as well as by the accumulation of facts, and I cheerfully resign my hypothesis and leave the field clear for others."

Professor McKenny Hughes thought the excavations showed conclusively that the monnds were artificial and not barrows. He inclined to the belief that they were salinæ, into which seawater was admitted at high tide when the sea used to come up to the west end, and that there were lower banks at the ends which had now disappeared, and which used to hold in the water.

\title{
THE PROBLEM OF THE EOLITHS.
}

By F. N. HaWakd.

Read at Norwich, March 1oth, 19r3.

\section{PART I.-RE "EXPERIMENTS ON FLINT CHIPPING" AND THEIR APPIICATION TO THE SOLUTION OF THE CHIPPING OF FLINT BY NATURE OR MAN.}

The fullest credit must be given to our members, Mr. Reid Moir, F.G.S., and Mr. S. Hazzledine Warren, F.G.S. (and others also) for their efforts to solve this problem by experiment. This is obviously the right line to adopt, but, after all, experiments (including my own, for I have been experimenting for years on similar lines) are only proof that (given suitable conditions) the sharp edges of split flints will chip under "Force," whether this is applied by Nature or Man. Experiments can prove the difference between the results of the forces of "Percussion" and "Pressure": but it is doubtful, in my opinion, if it can be proved by experiments whether Nature or Man has applied the force, as the same forces are used by both Nature and Man, the only difference being the intensity with which the force has been used and the way that force has been applied.

There is a great difference between the views held by various investigators. Mr. Reid Moir, in his interesting paper on "The Natural Fracture of Flint,"1 apparently considers he has been using "Natural Forces," implying thereby that "Nature's Methods" have been imitated, which is hardly correct. I think this is misleading, and must record my protest.

Among experiments which have been made, I would mention:-

(a) Shaking split Flints in a sack to simulate beach action.Which obviously it does not, for Nature does not confine stones as in a sack.

1 Proceedings Prehistoric Society of East Anglia. Tol. I., p. 171. 
(b) Attempting to split and chip Flints in a tube containing dry sand, under steady vertical pressure only (of a few tons), obtained by the use of a letter press. Whereas the flints should have been mixed with other stones (not soft sand, which acts like water) and varying lateral movement under great varying vertical pressure should bave been applied.

(c) Dragging by hand the sharp edge of a piece of split Flint along a concrete floor to simulate the action under a glacier. Where hundreds (even thousands) of tons pressure would be at work, not the paltry force of $1 \frac{1}{2} \mathrm{cwt}$. (12 stone) due to a man's weight or strength.

It is not a logical argument to say that-Because one produces a certain "result" (i.e., chipping on a flint) by a laboratory experiment conducted by human agency, therefore when apparently similar "results" are found in a gravel pit due to causes which we do not know, then these " results" must also be due to the only cause we actually can prove, namely, "Human Agency."

It is futile to insist on proof of Nature's Methods by actual experiment, or to insist on being shown Nature's "work" in actual progress. One must use one's reason. There are countless phenomena in Nature which no one can prove.

It is practically impossible to imitate by experiment the action taking place at the base of a glacier, or in an unstable surface deposit such as gravel, or to prove that Nature's forces can or cannot chip the edges of split flints or scratch their surfaces.

We have not now the required conditions for observation, but we have every reasonable circumstantial evidence that the conditions have occurred here time after time in the past, and may occur in the future, should this England of ours be again turned into a Greenland or a Spitzbergen, with all the attendant severities of climate.

Mr. Warren (who years ago held very similar views to those apparently now held by Mr. Moir) does not consider his experiments imitate Nature's methods. ${ }^{3}$ For many years Mr. Warren ha's been conducting a large series of experiments upon the result of "crushing" in the chipping of the edges of sharp flints. To obtain such "crushing forces" he has used crushing under a screw press; stamping and pressing with the heel; passage of cart wheel; and many other means adopted to bring into play movement of forces. It is obvious that none of these is strictly analagous to any "Natural Method," but the results supply a practical demonstration of the principle of "Chip and Slide" which I described in a previous paper on "The Chipping of Flints by Natural Agencies."

2 "On the Origin of Eolithic Flints by Natural Causes." Proceedings

Anthropological Inst, Dec., 1905.

3 Proceedings Prehistoric Society of East Anglia, Dec., 1911, Vol. I., p. 185. 
Mr. Warren also finds that whatever be the means adopted to crush the edges, the results always approximate the type of chipping observed on most of the "Eoliths" of the Kent Plateau. $\mathrm{He}$ also points out that where the crushing of flints in a deposit takes place, it seems inevitable that it should also follow similar lines, and that the striated surfaces so frequently associated with "Eolithic" chipping in geological deposits are suggestive of differential movements under pressure.

Although we may not all be prepared to agree with Mr. Warren in all details of his arguments, it must be admitted these facts are very damaging to the orthodox "Eolith theory."

Since experimenters differ so much in their conclusions, therefore the "laws" each may formulate as the result of his experiments should be applied with due regard to the fact that others may hold opposite opinions.

If applied with discretion, these experiments are valuable as "contributory evidence," but they ought not to be used (as they have been) as "main evidence" on which to base such comprehensive statements as to what Man only can do and Nature cannot.

It is ridiculous to suggest that a few laboratory experiments, made under artificial conditions, are equivalent to the action of Nature, whose forces are so varied, so complicated, and bring into play, so slowly and irresistibly, such immense pressures and movements of the soil (first in one direction and then another) during the many tens of thousands of years which have elapsed since the flint nodules were dragged out of the chalk, were split up into smaller sharp pieces, which were further chipped and redeposited, and gradually rolled into gravel; and also even since those gravels were deposited.

Further research may bring the solution, but only when investigators approach the problem from a different aspect to that only too frequently adopted by collectors who have not had extensive geological experience, and who, though they may have chipped flint, apply their results in such a way as not to obey the natural laws of "Cause and Effect."

\section{PART II.-PREFACE re KENTIAN EOLITHS.}

In attempting to discuss this topic, which is so to the front to-day, I wish to say that I am no "Anti-Eolithic" or "Natural Forces "fanatic, but one who has looked upon these problematic relics of the past with almost reverence, and still hopes that the existence of Pre-Palæolithic Man will be proved beyond question.

Few have greater respect than I have for the work done by such "Master Workers" as Sir Joseph Prestwich and Mr. Ben Harrison, to whom we young men owe so much (especially to Mr. Harrison, who has fought so valiantly to uphold the human origin of "Eoliths" of the Kent Plateau).

Years ago I not unnaturally accepted the opinion of workers older than myself that "Eoliths" were undoubtedly humanly 
chipped, and were Pre-Palæolithic, and were (because of their stratigraphical position) evidence of Pliocene Man.

There is no true analogy between the early controversy as to the human origin of Palæolithic Implements and the "Eolith" discussion of to-day. The discoveries made by the "Prehistorians" of fifty years ago were revolutionary in the extreme, and directly attacked the beliefs handed down as sacred from father to son for generations as to the age of the earth, etc. The early workers therefore were opposed tooth and nail by the geologically ignorant, and by all who held strong religious views. They were called infidels, and attacked by all the forces of all the Churches. Such an atmosphere practically does not exist to-day. We expect revolutionary discoveries to be made, and these are soon treated as a matter of course.

\section{re ROUGHNESS OF TOOLS USED BY SAVAGES.}

The argument is often used, that because the aborigines of Australia and Tasmania, etc, make and use very rough tools (often so rough as to be hardly recognisable as such), then also the English Pre-Palæolithic Man (if he existed) might also have produced similar apparently meaningless tools, i.e., the disputed "Eoliths." The analogy is a dangerous one, for its users forget the great difference in workability of the materials available in each country.

The Tasmanians had to use refractory stone. Had they possessed the fine flint (so plentiful in England) possibly their weapons and tools would have been of a very different order. The converse is equally probable. Had the English prehistoric flint workers (at their most skilful period) been suddenly obliged to use the Tasmanian stone, could they have heen able to do any better with such bad material? The beautiful spear points made of glass and telegraph insulators are evidence that the Australians can (if given suitable material) do very fine work ; and the roughness of their tools may therefore be due to the material used, and not necessarily to their state of civilisation.

Roughness of workmanship alone is therefore no proof of antiquity. It may be evidence of a primitive culture, but such exists to-day side by side with modern civilisation. We must also remember that, throughout all the ages, the work of the "prentice" lies associated with the finest product of the "Master Hand."

\section{re BIMILARITY OF SHAPE OF EOIITHS.}

It is noteworthy that practically every "Eolith" of the Kent Plateau consists of the outside portion (or "Steak") of flint bearing the original crust on the back, and a thermally split surface on the flat side, the edge of which is more or less "chipped," mostly in one direction.

Far too much importance has been attached to similarity of shape. In the first place, flints in each layer of the chalk are of 
very similar shapes, and would split by "Natural Agencies" (such as frost) into (more or less) similarly shaped pieces. It is common knowledge that a collection could easily be made of these constantly recurring definite shapes of absolutely unchipped sharp pieces of flint from deposits which have not been much rolled. Should these similar unchipped sharp pieces be later on ehipped on the edges by "Natural Forces," very similar resultant edge-chipped shapes would be produced.

The "Selective Instinct" of the collector would imperceptibly prompt him to pick up the best of these, and by the process of sorting "Good" from "Bad," some of the "Good" would be so alike as to form apparent types. First of all, the farm labourer picks up 100 likely stones and selects 10 of the best for the Collector, who in his turn also selects one or two of the "Best" and throws the "Rubbish" away. (This "Rubbish," however, possesses similar characteristics of "trimming" and abrasion on the edges as the "Best," but either jt is insufficient, or in the wrong place, or the shape is "wrong" and does not take the Collector's fancy.) Repeat this process with each Collector (and remember that most of these "picked" specimens eventually drift into the hands of a few large collectors), and in course of years this process of "selection" MUST result in an assembly of almost identical shapes.

Many times I have been met by this argument which an enthusiast uses as "proof" of the human origin of a disputed "Chipped Flint":--"See how it fits the hand!" This is Nor a logical argument, for the human hand is most adaptable and will "fit" stones of almost any shape.

\section{MECHANICS OF FLINT CHIPPING.}

Theoretically, there should be a border line where it is not possible to say whether Nature or Man has chipped the edge of a flint. In practice, however, this would not hold good, for Nature and Man, though they would use the same forces, would not do so in the same way, or with the same intensity.

The easiest "Force" for Man to adopt would be "Percussion," which could be applied by a little child as easily as by a strong man. There are so few occasions where Nature could use Percussion that this force can practically be eliminated so far as Nature is concerned.

The next likely "force" for Nature to adopt would be "Concussion" in the fortuitous churning up of a river or sea beach. This "force" Man is so unlikely to use that it can safely be ruled out so far as $\mathrm{HE}$ is concerned.

In the formation of the average "Eolith," I consider it is most probable that "Pressure" and "Abrasion" (or crushing of the edge) have had the principal say. Man's strength is such, that while he could with no great difficulty press off the first few small chips along a sharp edge, to press chips off four or five back from the original sharp edge (see Fig. 2), till the chipped facets 
are $90^{\circ}$ and even more with the flat surface, wonld, to my mind, require such force as no human being could apply by "Pressure." If "Percussion" were used, the characteristics of chipping would be very different to the average "Eolith." The rounded and battered edges could hardly have been the result of scraping wood or bone. IF they are the result of human work, one would almost think that they had been used to scrape, round sticks of stone (such as scythe sharpeners).

FiG. 2.

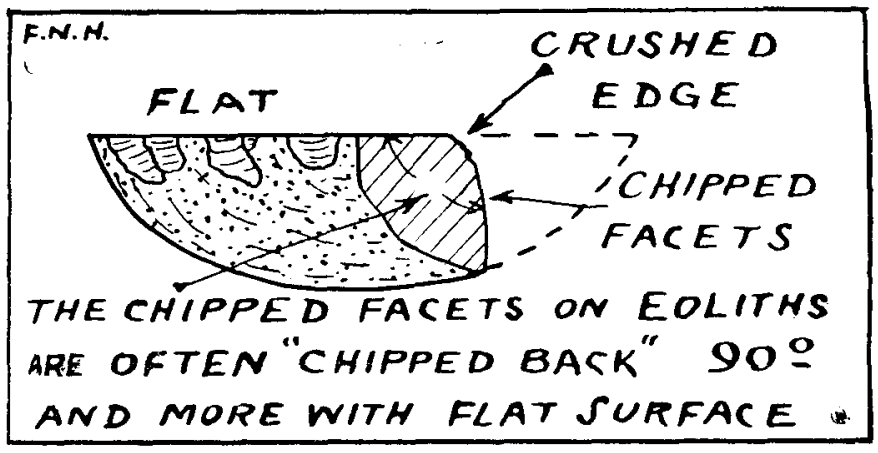

Nature, however, could, I believe, exert the required force under suitahle conditions, and the following suggestions may be the solution:-

FIG. 3.

Fig. 4.

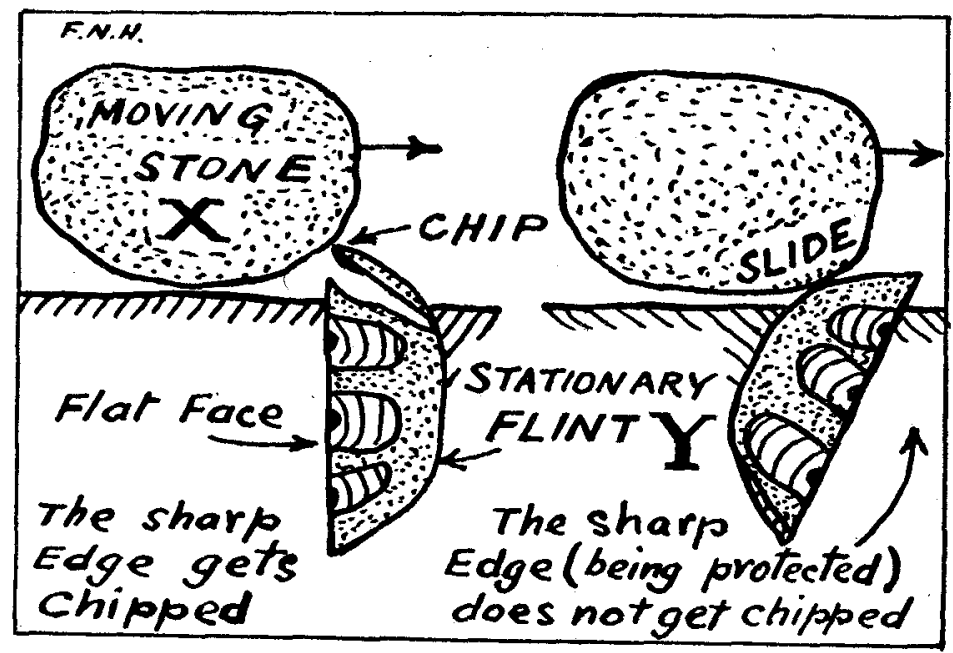

Fig. 3 illustrates how moving stones (X) would, when forced by Natural Agencies (such as ice, snow, or soil shift) against the sharp edge of stationary flints $(Y)$, bedded in the soil, force chips 
off from the sharp edge. The sharp chipped edge would continue to be chipped whenever the moving stones above touched the sharp edge, and in course of time a series of chips would be broken off.

Later (Fig. 4), the stationary flints would be forced over, and the moving stones above would simply slide over without touching the sharp edges of the split flints below.

Still later (Fig. 3), in course of the soil being cut away, the stationary flints would get forced over again, so that the sharp edges again faced the moving stones above, and another series of chips would be broken off.

Whichever side of a prece of flint the sharp edge was in the first place, that edge would be attacked and chipped by moving stones more frequently than the other.

In this way the split flints would be slowly broken up, and so-called "selective chipping" might be formed, due to this principle of "chip and slide," "chip and slide," as the stones were churned about. Naturally, all sorts of shapes would result, but probably certain types would prevail.

Hig. 5.

Fig. 6.

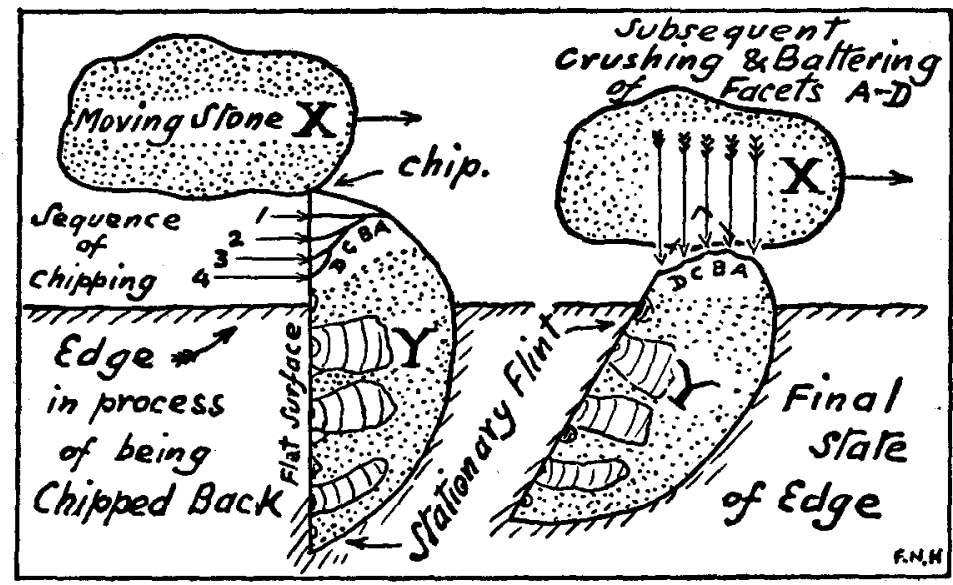

The following may account for the further chipping back of the edge (by pressure and crushing), and possibly may be the cause of some of the typical "Eolithic" edges.

Fig. 5.-The first crush of the moving stones $(\mathrm{X})$ against the sharp edge of stationary split flint (Y) would force chips No. 1 off the sharp edge.

The second crush would force chips No. 2 off, and so on as shewn above.

When the sharp edge of $\mathrm{Y}$ has been chipped back a definite distance from the original sharp edge (say to No. 4 chip, depending on size of flint), the moving stones could no longer find a sharp edge on which to chip. 
Fig. 6. - They would then stop chipping, and would slide over and further crush and batter the facets A to D till these assume. the characteristic apparently useless and worn-out edge so known to all students.

When this stage has been reached, the flint $\mathrm{Y}$ would be we1l on the way to becoming a rounded pebble.

re GEOLOGICAL AND STRATIGRAPHICAL POSITION OF EOLITHS.

If the "Eoliths" of the Kent Plateau are pre-Palæolithic Man's work, they are found in exactly the position our knowledge as to the evolution of Man and our earth's surface tells us they should be found-namely, at the highest altitudes above our present river systems.

The whole of our present knowledge of great geological changes in our earth's crust is based on observations extending back but a comparatively very few years. I therefore ask students of Man's pre-nistory (many of whom know far more about geological matters than I do) to take up the study of the origin of the so-called "Eoliths" again, and discuss the subject from another point of view. I believe that they will agree with me that, while a few may have been chipped by Man, further evidence will be required as to the exact geological and stratigraphical positions of those few.

When the "characteristics" of edge trimming of the "Eoliths" found in pits and on the surface are the same, then probably they were due to the same cause, either Nature or Man. If there is a difference (and I postulate there is), then they were probably due to different causes.

When the characteristics of edge trimming differ, then those few "Eoliths," the trimmed edges of which differ from the rest of the pit and surface "Eoliths," may have been chipped and used by the makers of the "old brown" and ochreous Palæolithic implements with which they are undoubtedly associated at times, both in pits (to a known depth of eight feet) and on the surface, or even by Man of a later period. The rest I cannot but help thinking are simply the result of "Natural Agencies."

So many excellent papers have been written on the geology of the Kent Plateau Drifts, that it need only be remarked that these old deposits are derived from the now vanished Wealden Heights, and are considered by many to be of Pliocene age, and possibly older.

Under the present surface there are quantities of "naturally" fractured flints with edge chipping, which would in course of time "weather out" and accumulate in the top soil. To-day, there are ploughed fields and pits where these split flints could be picked up for use, but Palæolithic Man had no such advantage, for the land was coyered by grass and forest. This is, I think, a point against the human origin of "Eoliths."

No deep sections have been exposed on the Plateau, and I venture to suggest that if a series of pits could be dug down to 
the chalk (exposing the "basement beds" of the drift and strata immediately above), unpatinated edge-chipped so-called "Eoliths" might be found, similar to those from the "Nature's Workshop Site" at Eaton, Norwich, which I have already described. ${ }^{8}$

\section{EVIDENCE OF SPECIMENS.}

Plates LXXXI. to XC. and Fig. 7 illustrate a series of typical "Eoliths" and "old brown" Palæoliths found in association, both in pits and on the surface of the Kent Plateau.

Our member, Mr. W. H. Cook, of Snodland, in his paper "On the Pre-Palæolithic Age of 'Eoliths,"' mentions that some of the Palæoliths from the Plateau are much more rolled and of a much deeper ochreous patina than the associated "Eoliths." It is also noteworthy that the edges of many of the Plateau Palæoliths are abraded similar to the edge-trimming of the "Eoliths" found in association. Frequently, the edges of both "old brown" Palæoliths and "Eoliths" from Kent Plateau have later chipping (judging from degrees of patination on same) of one and sometimes two later ages (see Plate XC.), due probably to crushing of stones in successive movements of the soil. I would also point out that the facets of edge-trimming of the average "Eolith" are very frequently indeed not patinated at all, but only slightly stained by the soil. Patination alone is no sure proof of age; it is far more evidence of the chemical conditions to which the flints have been subjected. If we are to judge of age by patination, then the trimmed edges of most of the "Eoliths" are obviously later than the Plateau Palæoliths.

To sum up the available information of the moment; it has been stated as a fact :-

1.-That "Palæoliths and 'Eoliths' are only found associated on the surface, and never in the drifts in situ."

(a) In contradiction to this, Plates LXXXI. and LXXXII. show rolled ochreous Palæoliths found in association with "Eoliths" in pits $4 \mathrm{ft}$. deep at 500 O.D., and 4 ft. 6 in. at 435 O.D.

(b) Fig. 7 shows sketches of two other important pit Palæoliths:- One: a portion of a much-rolled large "long ovoid" Palæolith, with highly-polished "old brown" patina, found (1910) $8 \mathrm{ft}$. deep in a pit at 688 O.D., close to the chalk escarpment at "The Vigo." The other: a typical ochreous Palæolithic flake with two distinct bulbs of percussion found (1888) $6 \mathrm{ft}$. deep in a section at 500 O.D. near Ash Church.

(c) An old Palæolith was found in situ in a horse grave pit dug at Terry's Lodge at 770 O.D.

2.- "Eoliths must be Pre-Palæolithic in age, because of the high levels at which they are found, the deep ochreous patina, and more rolled condition." Plates LXXXVII. to XC. illustrate 


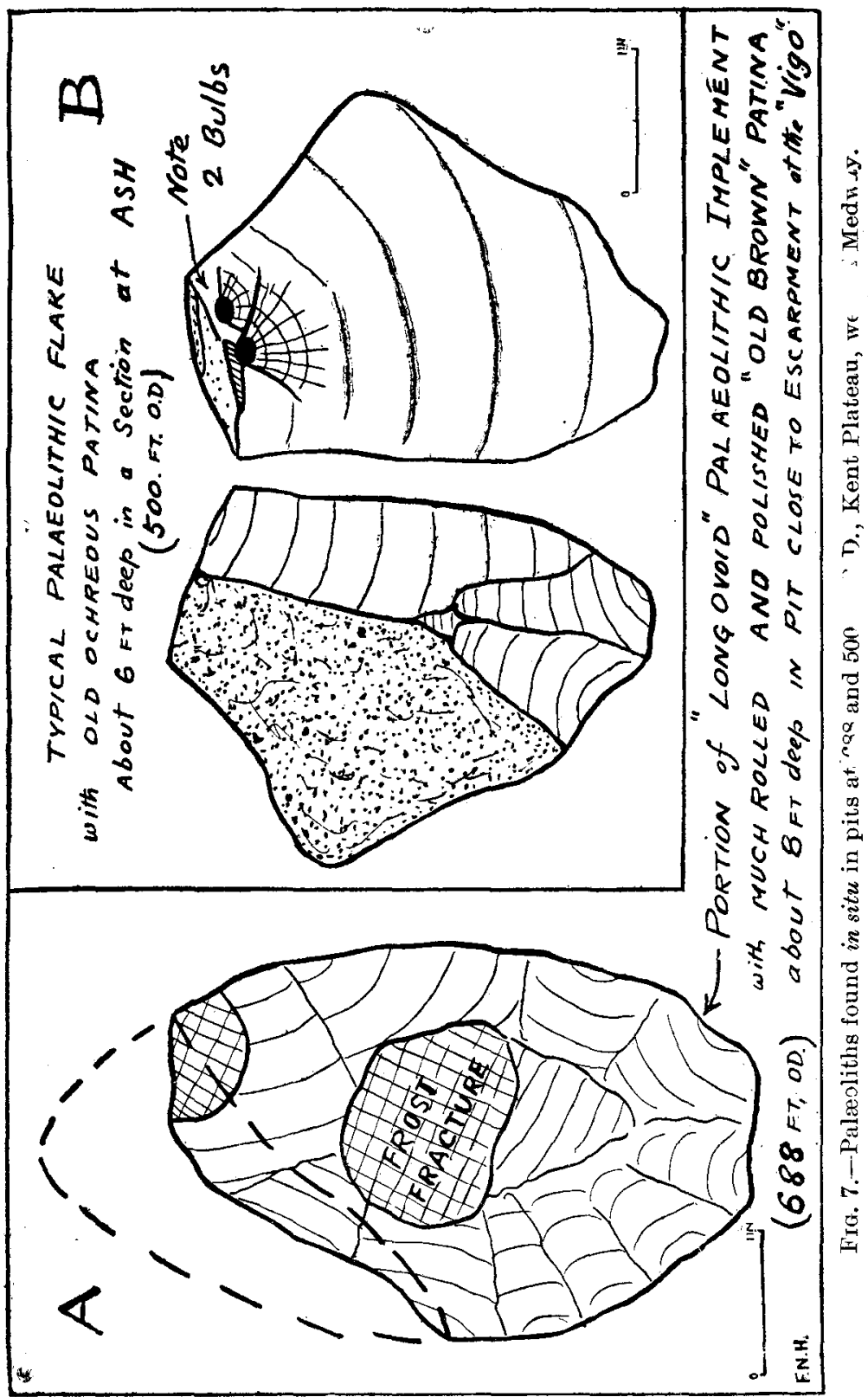


a series of Palæoliths found on the surface of the Plateau from 766 to 460 O.D. These show exactly similar conditions of "old brown" and ochreous patina and abrasion as the typical "Eoliths" from the same sites.

3.- "Palæoliths and Eoliths are not found associated on the surface of the Plateau at the higher levels, only on the lower levels."

Plate LXXVII. shows two Palæoliths from 766 and 740 O.D. Further examples are the Palæolith from 688 O.D, near the "Vigo," and the "Horse grave " Palæolith from 770 O.D, at Terry's Lodge, which are associated with Eoliths.

4.- " Palæoliths are later than the 'Eoliths' because of their less ochreous and less rolled condition." A glance at the specimens will show that this is not correct. Indeed, the trimmed edges of many of the "Eoliths" apparently are much later, as they are often not patinated at all.

5.- "Palæoliths and Eoliths are always brown or ochreous." Plate XCI. shows Palæoliths and associated Eoliths of perfectly white patina (500-460 O.D.), which disproves this point.

\section{CONCLUSION re EOLITHS.}

I do not think adequate attention has been paid to the characteristics of the edge chipping and abrasion on so-called "Eoliths." The Kent Plateau is a classic site, but "Eoliths" occur widely. From the Berkshire heights I have a series, which, though of no definite types ("Hollow Scrapers" are common) have in places exactly similar useless "chipped back" edges as the Kentian "Eoliths" (probably due to crushing).

The same remark is true of countless edge-chipped pieces from plateau or river gravels, or tiny bulbous flakes (size of $3 \mathrm{~d}$. piece) with edge-chipping ("Pygmy Palæolithic Implements!") picked up on a garden path, and which only a crank would say were humanly chipped.

I do not consider that the "Eoliths" are, as has been suggested, entirely an "exploded theory," but I do think that very few are humanly chipped, and, as to age, I see no evidence that they are of Pre-Palaeolithic culture, but, judging from the characteristics of chipping itselt, I consider they are no older, and probably later than the old Palæolithic implements of equal brown patina and mineral condition found in association with them.

In short, if the "Eoliths" are of Pliocene age, then the associated "old brown" and much-rolled Palæoliths must be older still.

\section{CONCLUSICNS re PLATEAU PALFOLITHS.}

The Palæoliths found on the Kent Plateau decidedly approximate in character to the Chellean and Acheulean implements from the 100-ft. Terrace of the Thames at Swanscombe. It would be hard to tell the difference if some of the latter were abraded on the edges, rolled, scratched, and iron-stained. 
The so-called Plateau is not a horizontal plain (as its name suggests); it is the northern slope of an anticline (due to the "uplift of the Weald"). As this uplift continued, it would tilt the surface of the land, so that it sloped more and more towards the Thames. This would cause the streams to flow faster and faster, and finally to run dry, except in periods of great rainfall.

There is no need to question slow upheavals and submergence, for we have proof of same in comparatively recent times. Since Roman days the lower Thames district has sunk 10-12 feet. Were it not for the river banks, the old Roman "Watling Street" at Rochester would now be 8 feet under water. Roman interments are also found deep under water level, and I do not suppose they used "caissons" to enable them to bury their dead.

At the present time (see Fig. 8) the fall from the chalk escarpment at "Terry's Lodge" (770 ft. O.D.) to the $100-\mathrm{ft}$. Terrace of the Thames at Swanscombe is $670 \mathrm{ft}$. in $9 \frac{1}{2}$ miles, which is too great a fall for a river system. What proof have we that this difference was as great in Palæolithic days?

The Plateau Palæoliths are found right up to the edge of the chalk escarpment. They are much water-worn, which pre-supposes extended river action. No river could have flowed under present stratigraphical conditions; therefore the Plateau must have extended far to the south, and a river system draining the surface must have existed before the Weald was excavated. Probably also there was no chalk escarpment, but the greensand rose to the surface of the higher land then existing.

The existence of these water-worn Palæoliths has to be accounted for. The deposits in which they are found may be (a) remnants of an old platform such as has been proved to have occurred about $750 \mathrm{ft}$. O.D in Cornwall and Devon, or (b) may be material washed out of ice coming from the north-east, or $(c)$ may be due to river systems draining the higher lands to the southward before the Weald was excavated. The solution must be left for geological research. I, however, feel justified in discussing the possibility of the last of the above suggestions.

Let us imagine ourselves (see Fig. 8) Palæolithic folk living on the river bank at Swanscombe. The Thames was then placidly flowing at "base level." There was a complete system of hills and dales, and tributary streams draining the uplands.

Suppose that when the Thames flowed at "base level" at Swanscombe, "Terry's Lodge" was then only 300 feet (or even less) above Swanscombe (i.e., that since then it has slowly risen 370 feet, due to continuance of "uplift"). This would be a reasonable fall for a river system or snow to deposit "drifts" of gravel or clay-with-flints.

If there is any truth in my suggestions, then these "old brown " and water-worn Palæoliths from the plateau may be of approximately the same age as those from Swanscombe, or bear the same relationship to them as Neoliths do to the present day. 


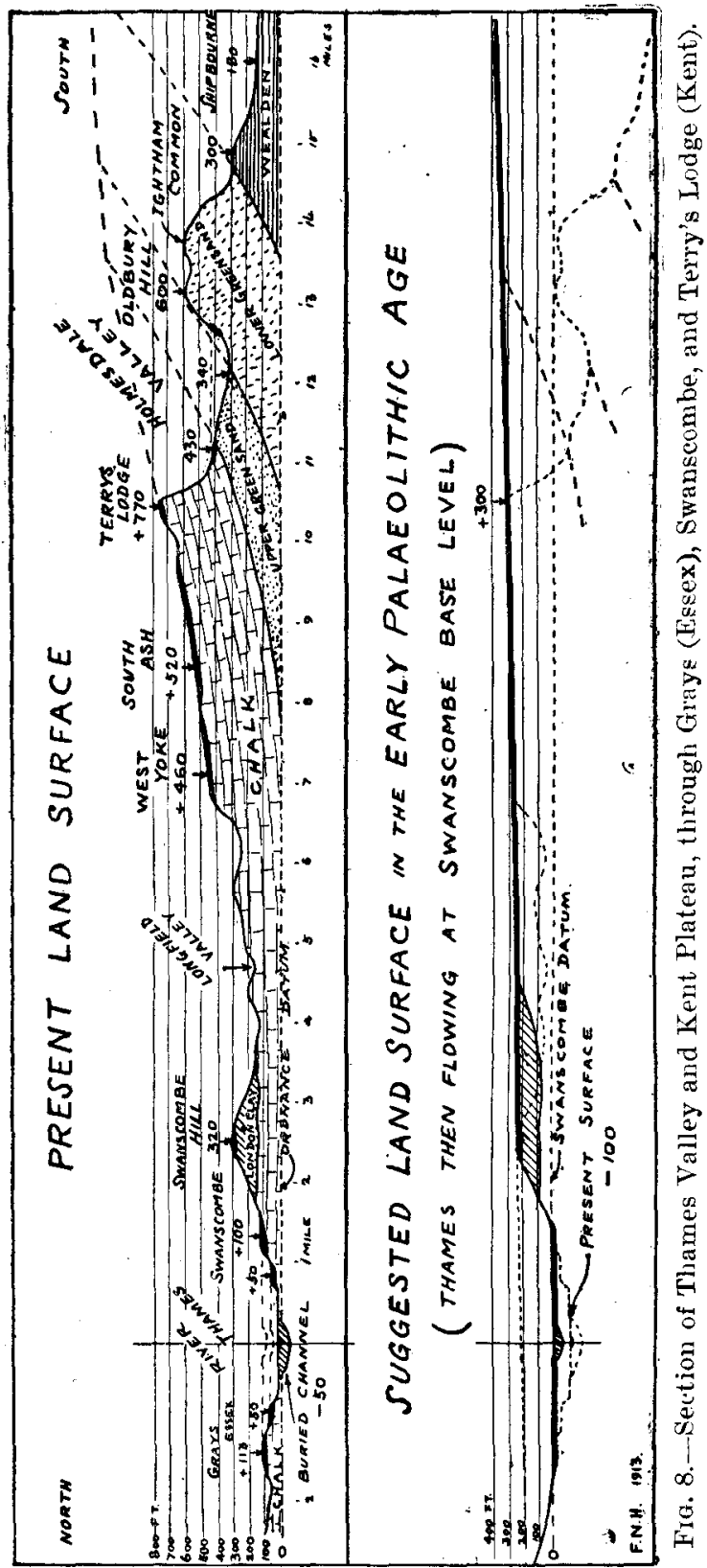

The author particularly wishes to express his indebtedness to Mr. B. B. Woodward, F.G.S., for his valuable criticism; also to Mr. W. H. Cook for the loan of specimens illustrated and the benefit of his observations. 


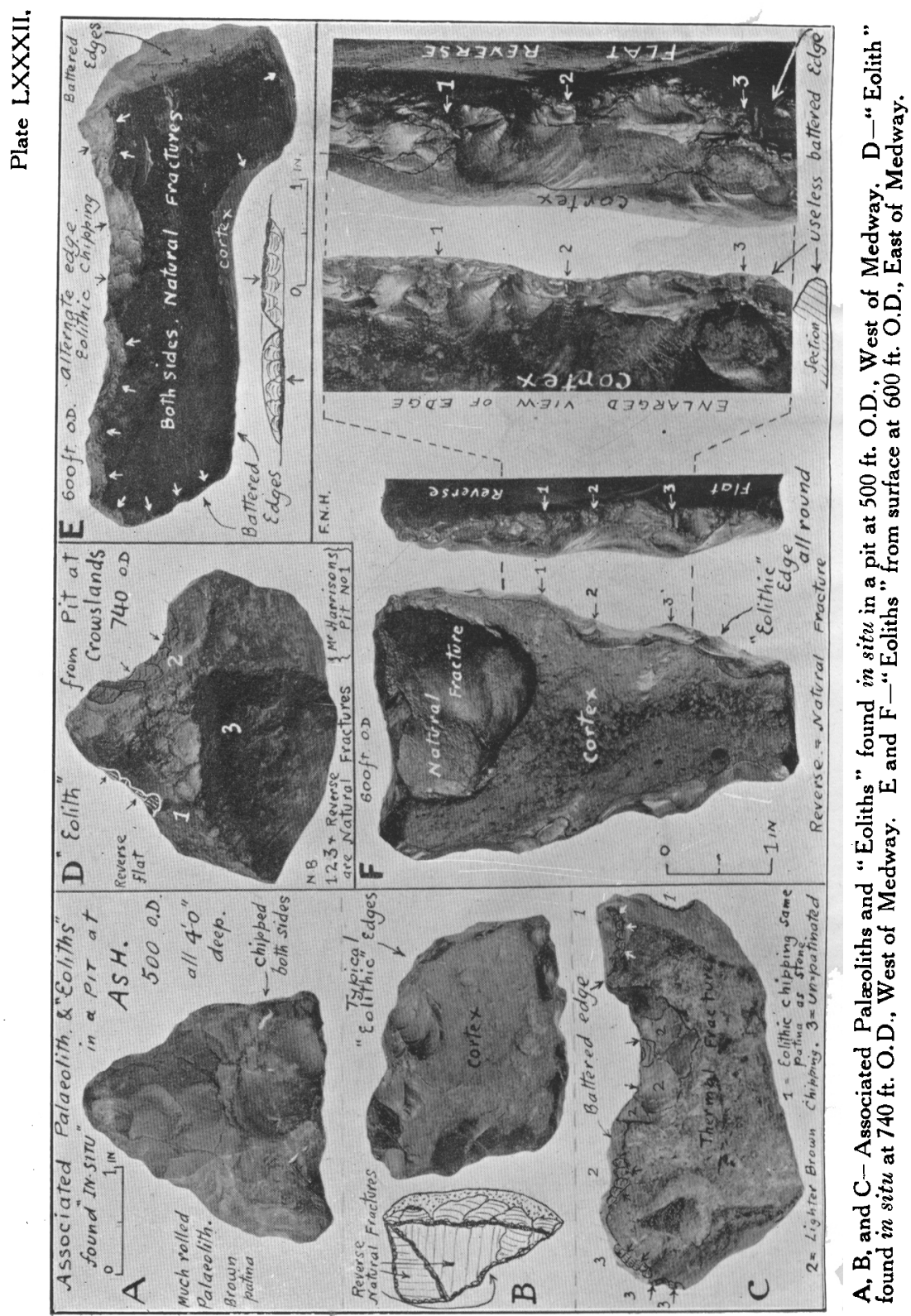




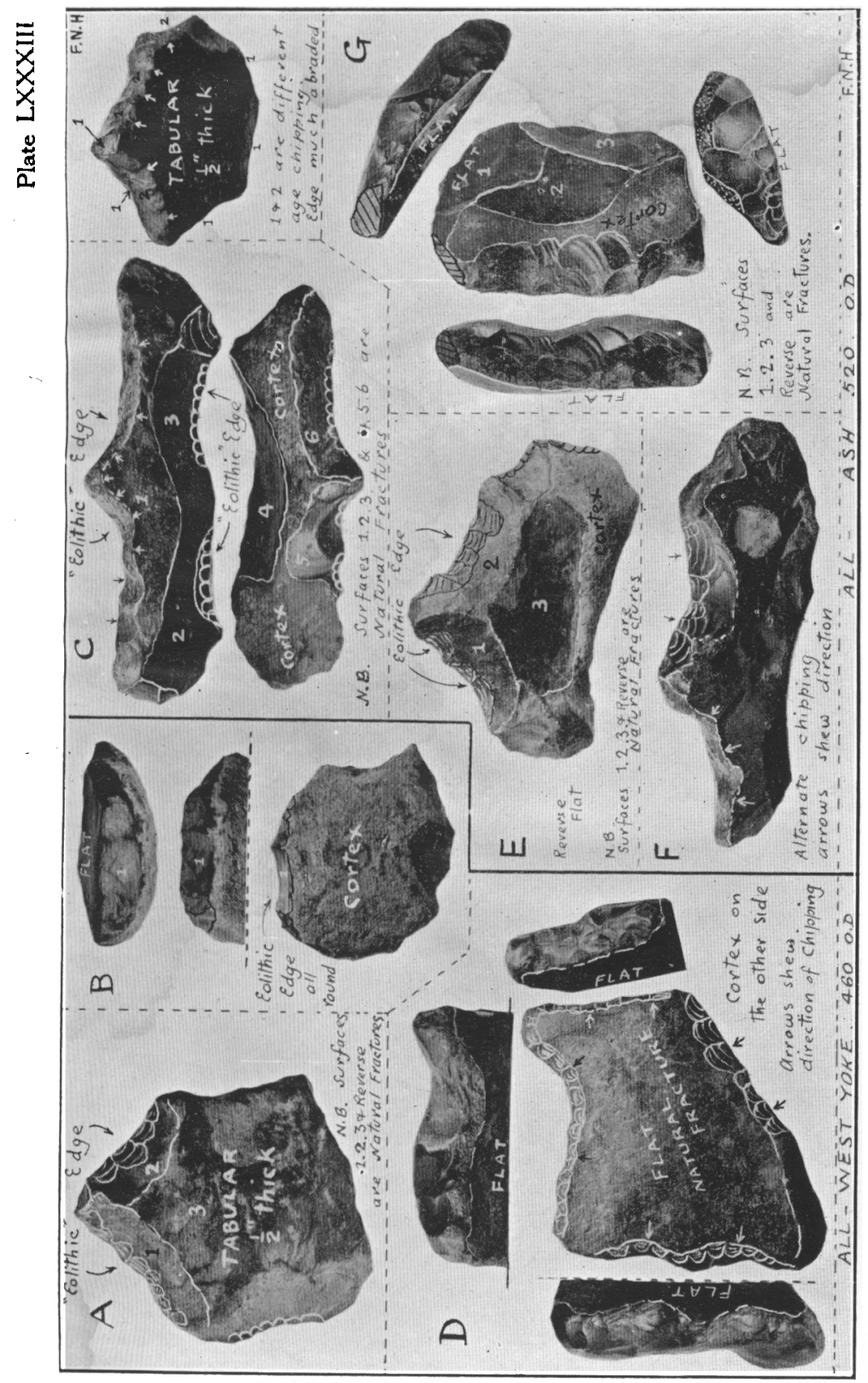

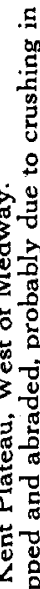

$0^{-3}$

0 융

ت

옹

in

동

83

于

is

边

至

焉

$=$

in

:

ㄴ.

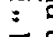

․․도

정

ค่

है

疍 


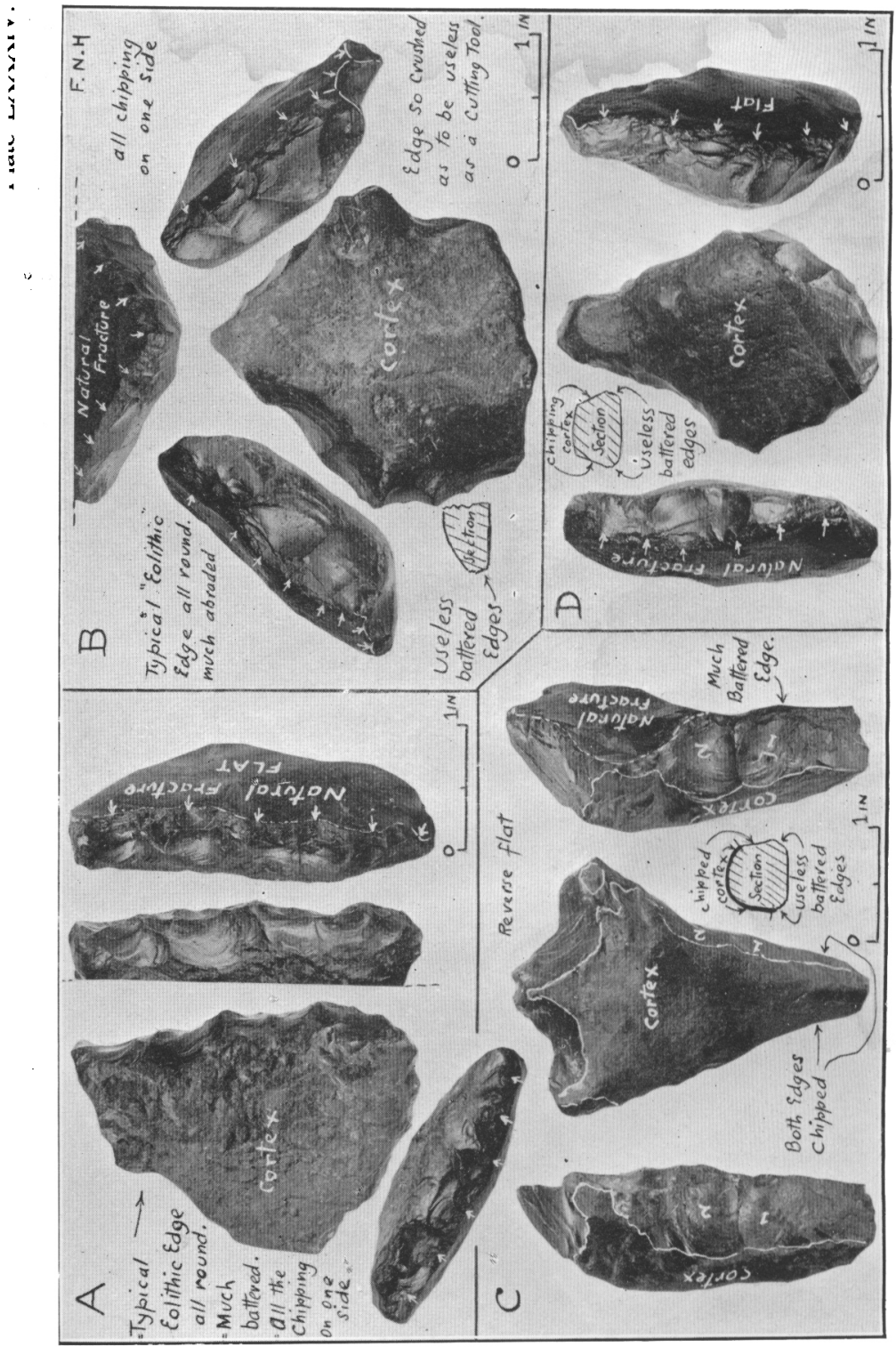

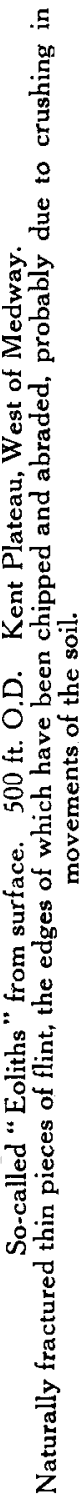






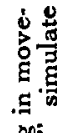

. \$ $9<$ 疋毕 $\sum_{1 \rightarrow \frac{2}{0}}$ ชั 苍 jं 疋 芯过 ค. 苞营: 计 Q.ํํํ 0. ث 율 in๊

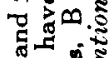

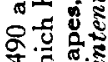
$\frac{1}{3}-\frac{1}{0}$ 엉 舫 귱 के के हू : تैة

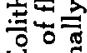
나의 $\rightarrow \quad 0$ 엉.

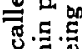

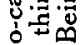
क ن 


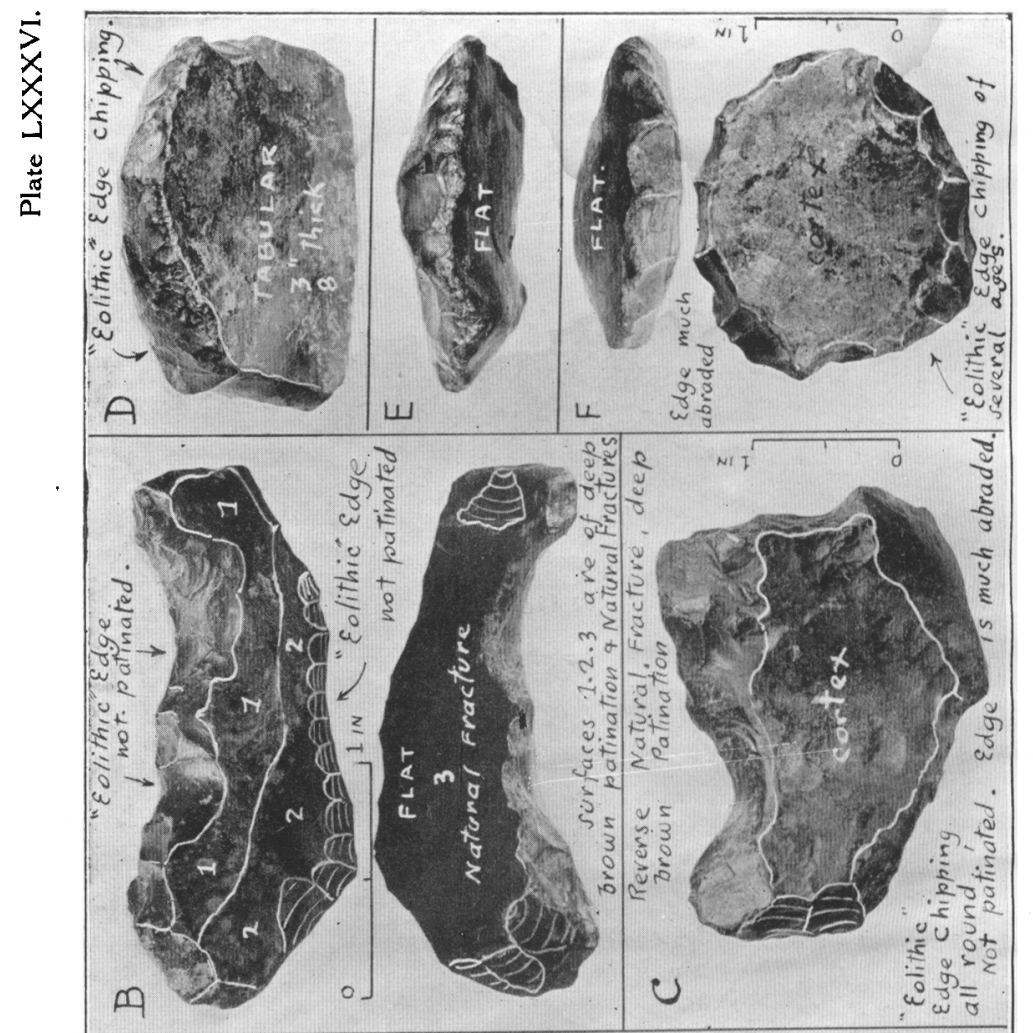

焉

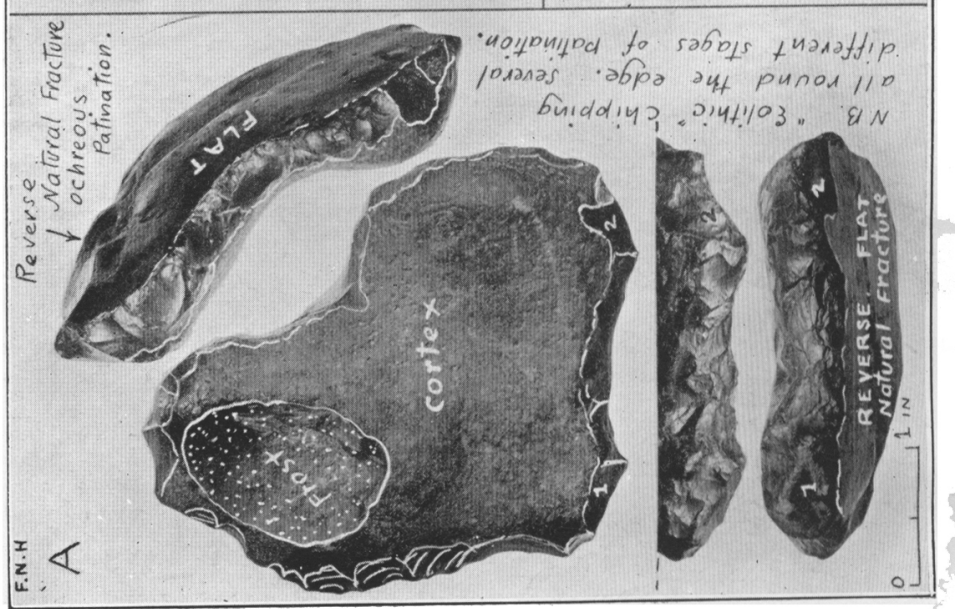

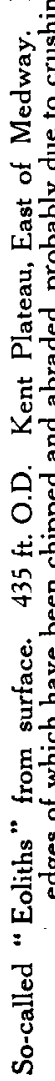




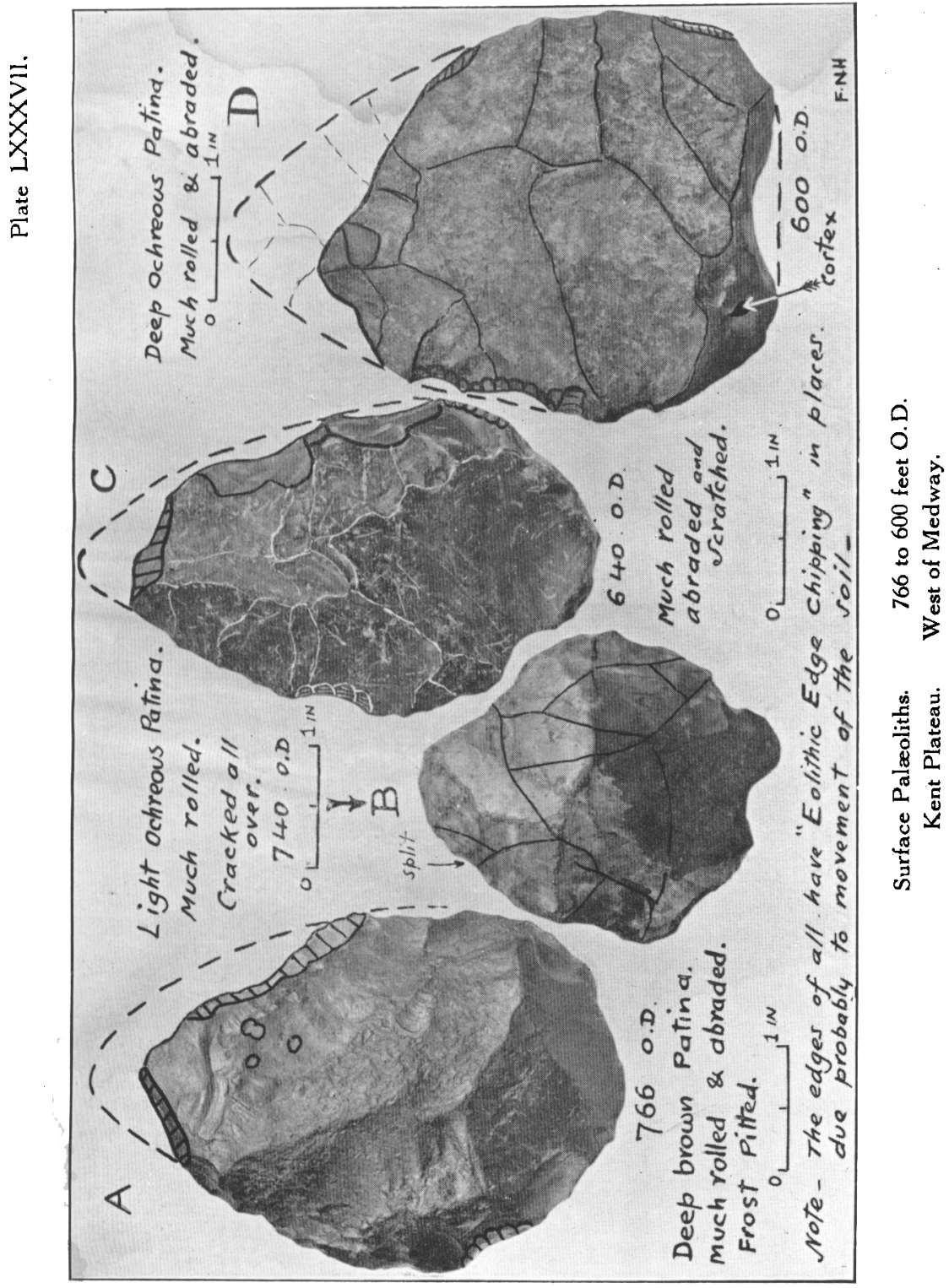




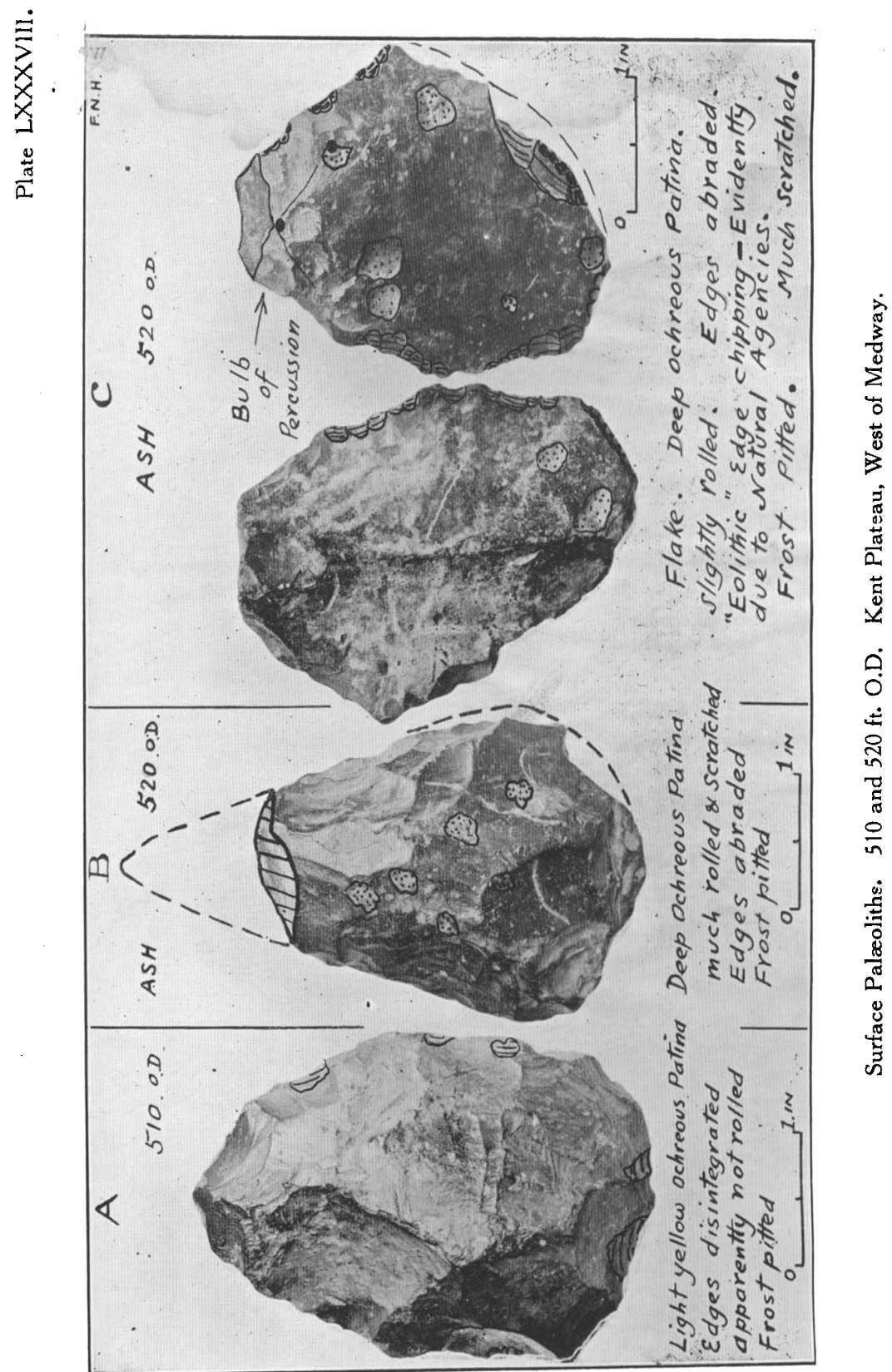




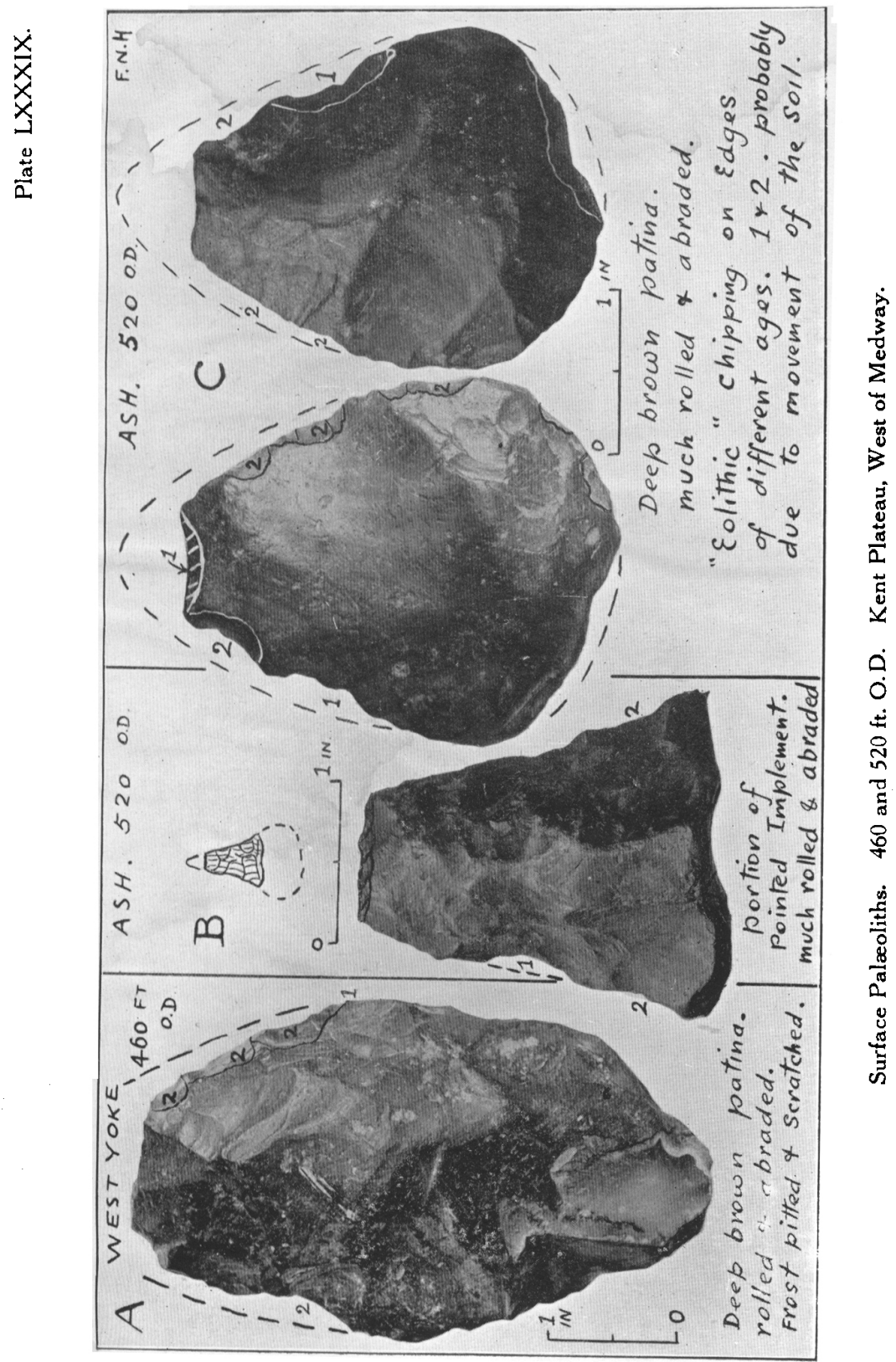


$\dot{x}$
$x$
0
$\frac{\pi}{a}$

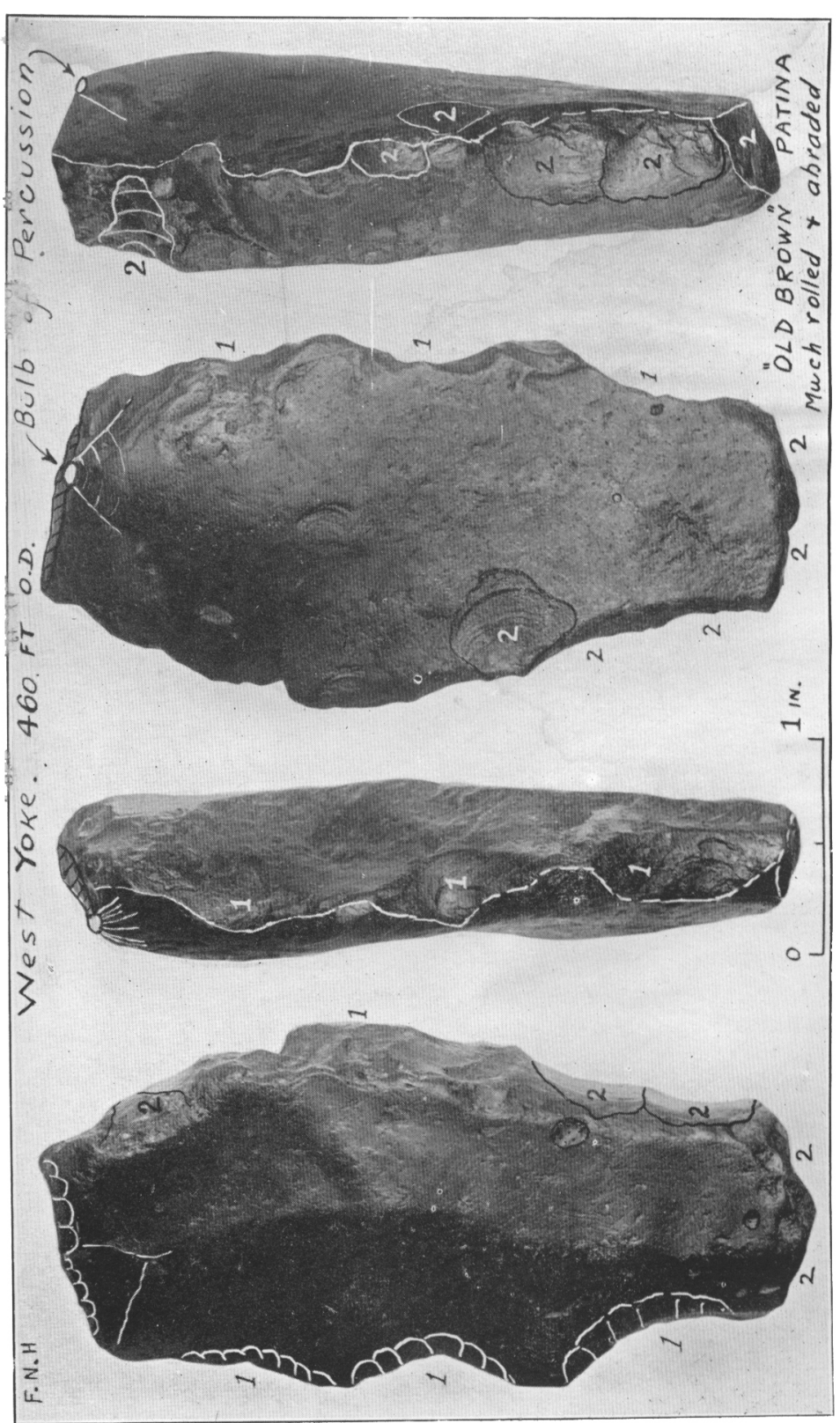

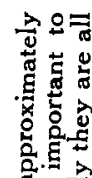

क.

สิ

38

要:

之焉

응

菏密

它

要宝安

- 5 .

苛

乙.वच

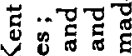

สक्ष -

它苋宠

$0 \cdot E \cdot g$ 車要造

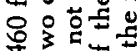

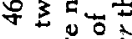
ปั

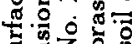

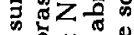

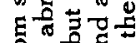
현 可 तै क力 늠을 을 武它要 용: డ. 跑

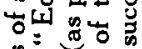
ऊ. 踪 $>$ a.s. 与 ठ․ वृ u동

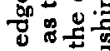
u 品直 동

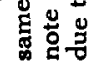




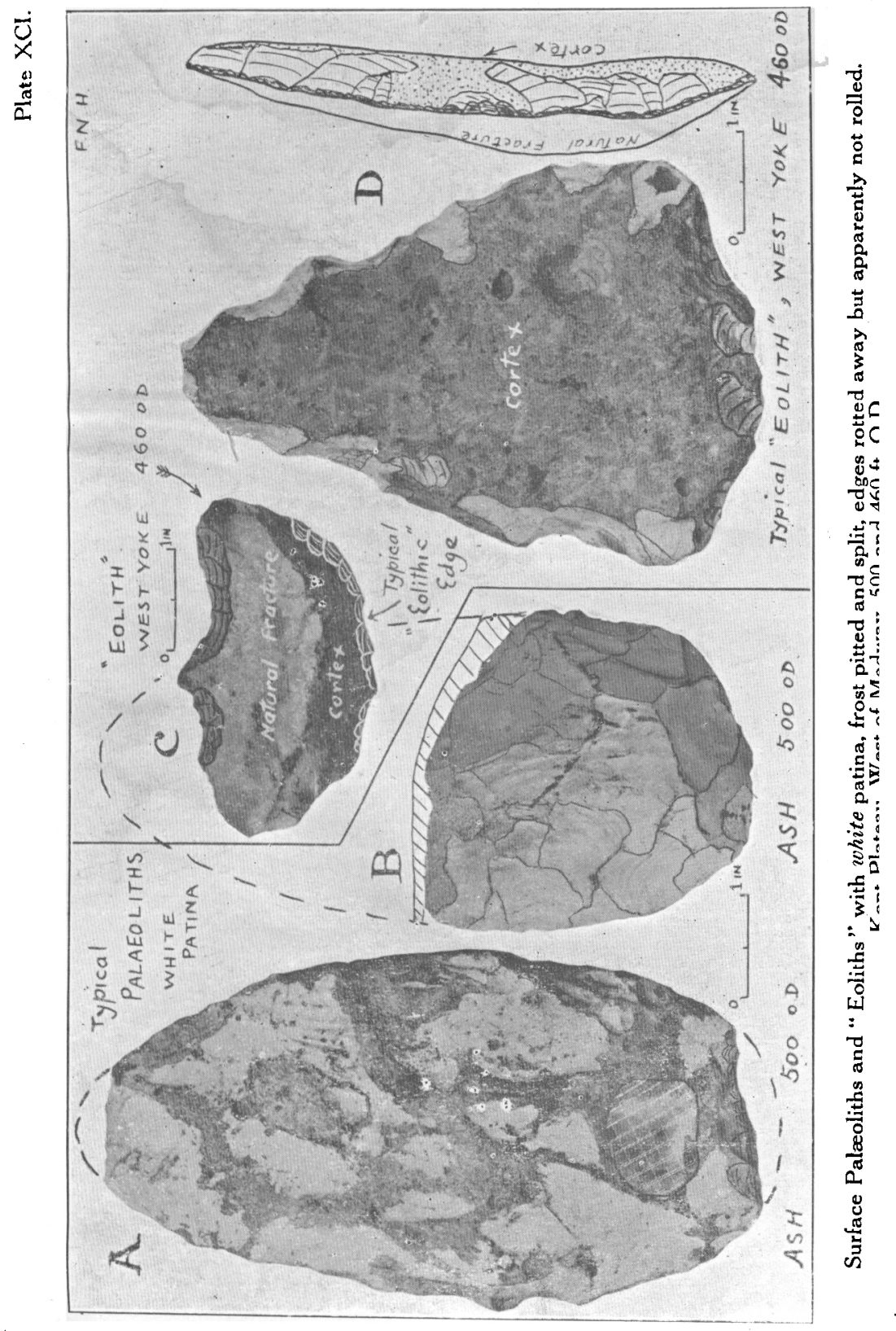

